\title{
Boron neutron capture therapy induces apoptosis of glioma cells through $\mathrm{Bcl}-2 / \mathrm{Bax}$
}

\author{
Peng Wang ${ }^{1 \dagger}$, Haining Zhen ${ }^{1 \dagger}$, Xinbiao Jiang ${ }^{2 \dagger}$, Wei Zhang ${ }^{1}$, Xin Cheng ${ }^{3}$, Geng Guo ${ }^{1}$, Xinggang Mao ${ }^{1}$, \\ Xiang Zhang ${ }^{1 *}$
}

\begin{abstract}
Background: Boron neutron capture therapy (BNCT) is an alternative treatment modality for patients with glioma. The aim of this study was to determine whether induction of apoptosis contributes to the main therapeutic efficacy of BNCT and to compare the relative biological effect (RBE) of BNCT, $\gamma$-ray and reactor neutron irradiation.

Methods: The neutron beam was obtained from the Xi'an Pulsed Reactor (XAPR) and $\gamma$-rays were obtained from $\left[{ }^{60} \mathrm{Co}\right] \gamma$ source of the Fourth Military Medical University (FMMU) in China. Human glioma cells (the U87, U251, and SHG44 cell lines) were irradiated by neutron beams at the XAPR or $\left[{ }^{60} \mathrm{Co}\right] \gamma$-rays at the FMMU with different protocols: Group A included control nonirradiated cells; Group B included cells treated with 4 Gy of $\left[{ }^{60} \mathrm{Co}\right] \gamma$-rays; Group C included cells treated with 8 Gy of $\left[{ }^{60} \mathrm{Co}\right.$ ] $\gamma$-rays; Group D included cells treated with 4 Gy BPA (p-boronophenylalanine)-BNCT; Group E included cells treated with 8 Gy BPA-BNCT; Group F included cells irradiated in the reactor for the same treatment period as used for Group D; Group $G$ included cells irradiated in the reactor for the same treatment period as used for Group E; Group H included cells irradiated with 4 Gy in the reactor; and Group I included cells irradiated with $8 \mathrm{~Gy}$ in the reactor. Cell survival was determined using the 3-(4,5-dimethylthiazol-2-yl2,5-diphenyltetrazolium (MTT) cytotoxicity assay. The morphology of cells was detected by Hoechst33342 staining and transmission electron microscope (TEM). The apoptosis rate was detected by flow cytometer (FCM). The level of $\mathrm{BCl}-2$ and Bax protein was measured by western blot analysis.
\end{abstract}

Results: Proliferation of U87, U251, and SHG44 cells was much more strongly inhibited by BPA-BNCT than by irradiation with $\left[{ }^{60} \mathrm{Co}\right]$-rays $(P<0.01)$. Nuclear condensation was determined using both a fluorescence technique and electron microscopy in all cell lines treated with BPA-BNCT. Furthermore, the cellular apoptotic rates in Group D and Group E treated with BPA-BNCT were significantly higher than those in Group B and Group C irradiated by $\left[{ }^{60} \mathrm{Co}\right] \gamma$-rays $(P<0.01)$. The clonogenicity of glioma cells was reduced by BPA-BNCT compared with cells treated in the reactor (Group F, G, H, I), and with the control cells $(P<0.01)$. Upon BPA-BNCT treatment, the Bax level increased in glioma cells, whereas $\mathrm{BCl}-2$ expression decreased.

Conclusions: Compared with $\gamma$-ray and reactor neutron irradiation, a higher RBE can be achieved upon treatment of glioma cells with BNCT. Glioma cell apoptosis induced by BNCT may be related to activation of Bax and downregulation of $\mathrm{BCl}-2$.

\section{Background}

Glioma is one of the most aggressive human malignancies. Despite aggressive surgery combined with adjuvant radiotherapy and chemotherapy, patient prognosis remains poor. It is thus essential to develop novel

\footnotetext{
* Correspondence: xzhang@fmmu.edu.cn

† Contributed equally

'Department of Neurosurgery of Xijing Hospital, Fourth Military Medical University, Xi'an, Shaanxi 710032, P.R.China

Full list of author information is available at the end of the article
}

therapeutic strategies to treat glioma. Boron neutron capture therapy (BNCT) is a highly selective treatment modality that can target the tumor without causing excessive radiation damage to the normal tissues [1]. The ability of $\left[{ }^{10} \mathrm{~B}\right]$ to capture thermal neutrons, and to then disintegrate immediately into a He nucleus (an $\alpha$ particle) and a Li nucleus, is utilized in BNCT [2]. Both the $\mathrm{He}$ and $\mathrm{Li}$ nuclei have high lineal energy transfer (LET) values, with path-lengths approximately the diameter of a single cell; the lethality of these nuclei is thus
C Biomed Central

(c) 2010 Wang et al; licensee BioMed Central Ltd. This is an Open Access article distributed under the terms of the Creative Commons Attribution License (http://creativecommons.org/licenses/by/2.0), which permits unrestricted use, distribution, and reproduction in any medium, provided the original work is properly cited. 
primarily limited to boron-containing cells [3]. BNCT has been carried out in numerous studies using syngeneic rat gliomas [3-6]. Approaches such as administering $\left[{ }^{10} \mathrm{~B}\right]$ by intra-arterial injection with or without blood-brain barrier (BBB) disruption [7-9], or intracerebral delivery of high molecular weight agents by means of convection enhanced delivery following neutron beam irradiation $[2,10]$, confirm that BNCT is highly effective for treatment glioma xenograft models. In clinic, BNCT has been used in various countries to treat patients with high-grade glioma, melanoma, liver metastasis of colon adenocarcioma, malignant melanomas, oral cancer, and therapeutically refractory, recurrent tumors of the head and neck [3,6,11-15]; while the mechanism of BNCTinduced cell death remains unclear.

We treated U87, U251, and SHG44 glioma cells with BNCT in vitro, using L-p-borono-phenylalanine (L-BPA) as the boron carrier and the thermal neutron source of the Xi'an Pulsed Reactor (XAPR) in China as the irradiator. The relative biological effect (RBE) of BNCT on tested cells, especially with respect to apoptosis induction, was assessed, and a possible mechanism of BNCT action was presented.

\section{Methods}

\section{Glioma cell culture}

The human glioblastoma multiforme cell lines U87 and U251 were obtained from the American Type Culture Collection (ATCC; Manassas, VA). The human anaplastic astrocytoma cell line SHG44 was purchased from the Institute of Biochemistry and Cell Biology (IBCB; Shanghai, China). Cells were cultured in Dulbecco's modified Eagle's medium (DMEM) (Gibco, Grand Island, NY) with $10 \%(\mathrm{v} / \mathrm{v})$ fetal bovine serum (Gibco) and $0.5 \%$ (w/v) penicillin-streptomycin solution (Gibco), at $37^{\circ} \mathrm{C}$ under $5 \% \mathrm{CO}_{2}$ and $95 \%$ air (both v/v).

\section{Boron uptake by glioma cells in vitro}

$\left[{ }^{10} \mathrm{~B}\right]$-enriched L-BPA (Ryscor Inc., Raleigh, NC) was used in the study. L-BPA was added to the culture media of glioma cells to $50 \mu \mathrm{g}\left[{ }^{10} \mathrm{~B}\right] / \mathrm{ml}$. Cells in the exponential phase of growth were cultured in boroncontaining medium for $3,6,12$, or 24 h before harvesting, and boron concentrations were determined by inductively coupled plasma atomic emission spectroscopy (ICP-AES) (VISTA-MPX; Varian Co., Walnut Creek, CA) according to a previously described method [16].

\section{In vitro irradiation}

In vitro irradiation of the three cell lines was performed using the neutron beam at the XAPR whereas in vitro $\gamma$-ray irradiation by the $\left[{ }^{60} \mathrm{Co}\right] \gamma$ source was performed in the Fourth Military Medical University (Xi'an, China).
Cells were divided into nine groups. Group A was control nonirradiated cells; Group B cells were irradiated with 4 Gy of $\left[{ }^{60} \mathrm{Co}\right] \gamma$-rays; Group C cells were irradiated with 8 Gy of $\left[{ }^{60} \mathrm{Co}\right] \gamma$-rays; Group D cells were irradiated with 4 Gy BPA-BNCT; Group E cells were irradiated with 8 Gy BPA-BNCT; Group F cells were irradiated in the XAPR for the same treatment period as used for Group D; Group G cells were irradiated in the XAPR for the same treatment period as used for Group E; Group $\mathrm{H}$ cells were irradiated with $4 \mathrm{~Gy}$ in the XAPR; and Group I cells were irradiated with 8 Gy in the XAPR. In Group D and Group E with BPA-BNCT, cells were incubated for $24 \mathrm{~h}$ in medium with BPA and washed three times with phosphate-buffered saline (PBS); the medium was next replaced with boron-free medium; cells were exposed to the XAPR with irradiation doses of $4 \mathrm{~Gy}$ and $8 \mathrm{~Gy}$, respectively. In the $\gamma$-raytreated Group B and Group C, cells incubated in growth medium without BPA were exposed to the $\gamma$-rays with irradiation doses of $4 \mathrm{~Gy}$ and $8 \mathrm{~Gy}$, respectively. In Group F and Group G, cells incubated in medium without BPA were exposed to the XAPR with identical treatment durations of Group D and Group E, respectively. In Group $\mathrm{H}$ and Group I, cells incubated in growth medium without BPA were exposed to the XAPR with irradiation doses of $4 \mathrm{~Gy}$ and $8 \mathrm{~Gy}$, respectively. Irradiated and nonirradiated cells were placed at room temperature and under a normal atmosphere during irradiation. At the beginning of the experiment, all cells were in the exponential phase of growth and at a density of $3 \times 10^{5} / \mathrm{ml}$. The components of the reactor neutron source and the $\left[{ }^{60} \mathrm{Co}\right] \gamma$ source were shown in Table 1; the irradiation periods of various groups were listed in Table 2; the dose components of BNCT were listed in Table 3 and Table 4. The irradiation doses were calculated according to previous studies $[17,18]$.

\section{Proliferation assays}

Cell survival was determined using the 3-(4,5dimethylthiazol-2-yl-2,5-diphenyltetrazolium (MTT) (Sigma, St. Louis, MO) assay. After irradiation, cells were trypsinized and washed, and cell concentrations were adjusted to $10^{4}$ cells $/ \mathrm{ml}$. Cells were seeded into the

Table 1 Dose rates for reactor neutron source and [60Co] $\gamma$ source

\begin{tabular}{lll}
\hline & Components & Dose rate (Gy/min) \\
\hline \multirow{2}{*}{$\begin{array}{l}\text { Dose rates for the reactor } \\
\text { neutron source }\end{array}$} & Thermal neutron & $1.04 \times 10^{-3}$ \\
& Epithermal neutron & $2.48 \times 10^{-4}$ \\
& Fast neutron & $1.07 \times 10^{-1}$ \\
& ${ }^{10} \mathrm{~B}(\mathrm{n}, \alpha)^{7} \mathrm{Li}$ & $1.57 \times 10^{-2}$ \\
\hline Dose rate for the $\left.{ }^{[00} \mathrm{Co}\right] \gamma$ source & $5.09 \times 10^{-4} / \mathrm{ppm}^{10} \mathrm{~B}$ \\
\hline
\end{tabular}


Table 2 The irradiation periods of various groups

\begin{tabular}{lccccccccc}
\hline & $\begin{array}{c}\text { Group A } \\
(\mathbf{m i n})\end{array}$ & $\begin{array}{c}\text { Group B } \\
(\mathbf{m i n})\end{array}$ & $\begin{array}{c}\text { Group C } \\
(\mathbf{m i n})\end{array}$ & $\begin{array}{c}\text { Group D } \\
(\mathbf{m i n})\end{array}$ & $\begin{array}{c}\text { Group E } \\
(\mathbf{m i n})\end{array}$ & $\begin{array}{c}\text { Group F } \\
(\mathbf{m i n})\end{array}$ & $\begin{array}{c}\text { Group G } \\
(\mathbf{m i n})\end{array}$ & $\begin{array}{c}\text { Group H } \\
(\mathbf{m i n})\end{array}$ & $\begin{array}{c}\text { Group I } \\
(\mathbf{m i n})\end{array}$ \\
\hline U87 & 64 & 0.29 & 0.57 & 27 & 54 & 27 & 54 & 32 & 64 \\
U251 & 64 & 0.29 & 0.57 & 25 & 50 & 25 & 50 & 32 & 64 \\
SHG44 & 64 & 0.29 & 0.57 & 28 & 56 & 28 & 56 & 32 & 64 \\
\hline
\end{tabular}

wells of 96-well microplates (Nunc, Roskilde, Denmark) and incubated for 2, 4, or 6 days. The culture medium was removed and replaced with $100 \mu \mathrm{l}$ aliquots of fresh medium, without serum, containing $0.5 \mathrm{mg} / \mathrm{ml} \mathrm{MTT}$, followed by $4 \mathrm{~h}$ of incubation at $37^{\circ} \mathrm{C}$. Next, medium was aspirated from the wells and $100 \mu \mathrm{l}$ dimethyl sulfoxide (DMSO) was added to each well, to dissolve formazan crystals. Optical density (OD) was measured using an enzyme-linked immunosorbent method. Cell numbers were derived from OD values by reference to a standard cell number-OD curve.

\section{Hoechst staining}

At $12 \mathrm{~h}, 24 \mathrm{~h}, 36 \mathrm{~h}$, and $48 \mathrm{~h}$ after treatment with BPABNCT, cells were fixed for $10 \mathrm{~min}$ in $4 \%(\mathrm{v} / \mathrm{v})$ paraformaldehyde, and then incubated with Hoechst 33342 dye (Sigma) $(10 \mu \mathrm{g} / \mathrm{ml})$ for $10 \mathrm{~min}$. After washed with PBS, cells were observed using an inverted fluorescence microscope (IX70; Olympus, Tokyo, Japan).

\section{Electron microscopy}

Forty-eight hours after irradiation, cells were detached from plates, washed, suspended in PBS, and concentrated by centrifugation. Cell samples were fixed in $2.5 \%$ (v/v) glutaraldehyde in $0.1 \mathrm{M}$ phosphate buffer ( $\mathrm{pH} 7.4)$, postfixed in $2 \%(\mathrm{w} / \mathrm{v})$ buffered osmium tetroxide for $2 \mathrm{~h}$, and dehydrated in ethanol. Specimens for transmission electron microscopy were embedded in Epon. Thin sections were cut using an ultramicrotome and doublestained with uranyl acetate and lead citrate. Electron micrography was performed (JEM-2000EX; JEOL, Tokyo, Japan) using an operating voltage of $80 \mathrm{kV}$.

\section{AnnexinV/PI analysis}

Twelve hours, $24 \mathrm{~h}, 36 \mathrm{~h}$, and $48 \mathrm{~h}$ after irradiation, cells were trypsinized, counted, washed twice in ice-cold PBS solution, and resuspended in $1 \times$ binding buffer (10 $\mathrm{mM}$ HEPES/NaOH [pH 7.4], $140 \mathrm{mM} \mathrm{NaCl}$, and 2.5 $\mathrm{mM} \mathrm{CaCl}$ ). Next, $5 \mu \mathrm{l}$ of annexin V-FITC (AV) (R\&D
Systems Europe Ltd., Abingdon, UK) and $10 \mu \mathrm{l}$ of propidium iodide (PI) (Sigma) were added to $100 \mu \mathrm{l}$ of cell suspension, followed by incubation for $15 \mathrm{~min}$ at room temperature in the dark. Finally, $400 \mu \mathrm{l}$ of binding buffer was added to each sample, which was held on ice prior to analysis on a FACSCalibur (Becton Dickinson Labware, Franklin Lakes, NJ) flow cytometer. Ten thousand cells per sample were analyzed.

\section{Clonogenic assay}

After irradiation, 200 treated cells were plated in sixwell flat-bottomed microplates (Nunc) and incubated at $37^{\circ} \mathrm{C}$ in a humidified incubator under $5 \%(\mathrm{v} / \mathrm{v}) \mathrm{CO}_{2}$ for 2 weeks. The cells were fixed in methanol and stained with Giemsa's solution. Colonies $\geq 50 \mu \mathrm{m}$ in diameter were counted [19].

\section{Western blot analysis}

Twelve hours and $24 \mathrm{~h}$ after irradiation, cells were washed twice in ice-cold PBS and protein extracts of U87, U251, and SHG44 cells were prepared by lysis in RIPA buffer $(150 \mathrm{mM} \mathrm{NaCl}, 1 \%$ [v/v] NP-40, 0.5\% [w/v] sodium deoxycholate, $0.1 \%[\mathrm{w} / \mathrm{v}]$ sodium dodecyl sulfate (SDS), $50 \mathrm{mM}$ Tris $\mathrm{HCl}[\mathrm{pH}$ 8], $10 \mathrm{mM}$ EDTA, and 1 mM PMSF [Sigma]) for $30 \mathrm{~min}$ at $4{ }^{\circ} \mathrm{C}$. Samples were next centrifuged for $15 \mathrm{~min}$ at 15,000 g. Protein concentrations of supernatants were determined. For each sample, $60 \mu \mathrm{g}$ of protein was loaded on a $12.5 \%(\mathrm{w} / \mathrm{v})$ SDS-polyacrylamide gel, electrophoresed, and transferred to a nitrocellulose membrane (Protran; Schleicher and Schuell, Florham Park, NJ). Each membrane was blocked for $1 \mathrm{~h}$ at room temperature with blocking buffer (TBS containing 0.1\% [v/v] Tween 20 [Sigma] and $5 \%[\mathrm{w} / \mathrm{v}]$ milk powder). Primary antibodies (applied for $1 \mathrm{~h}$ at room temperature, or overnight at $4^{\circ} \mathrm{C}$ ) were: anti-Bcl-2 (Santa Cruz Biotechnology, Inc., Heidelberg, Germany), anti-Bax (Santa Cruz), and anti-actin (mouse monoclonal C-2, Santa Cruz). Antibodies were diluted $1: 1,000$, except for the anti-actin antibody (1:500).

Table 3 The dose components of BNCT 4 Gy

\begin{tabular}{lccccc}
\hline & Thermal neutron (Gy) & Epithermal neutron (Gy) & Fast neutron (Gy) & $\boldsymbol{\gamma}$-ray (Gy) & ${ }^{\mathbf{1 0}} \mathbf{B}(\mathbf{n}, \boldsymbol{\alpha})^{\mathbf{7}} \mathbf{L i}(\mathrm{Gy})$ \\
\hline U87 & 0.028 & 0.007 & 2.889 & 0.423 & 0.653 \\
U251 & 0.026 & 0.007 & 2.675 & 0.392 & 0.900 \\
SHG44 & 0.029 & 0.007 & 2.996 & 0.439 & 0.529 \\
\hline
\end{tabular}


Table 4 The dose components of BNCT 8 Gy

\begin{tabular}{|c|c|c|c|c|c|}
\hline & Thermal neutron (Gy) & Epithermal neutron (Gy) & Fast neutron (Gy) & $\gamma$-ray (Gy) & ${ }^{10} \mathrm{~B}(\mathrm{n}, \alpha)^{7} \mathrm{Li}(\mathrm{Gy})$ \\
\hline U87 & 0.056 & 0.013 & 5.778 & 0.846 & 1.306 \\
\hline U251 & 0.052 & 0.013 & 5.350 & 0.748 & 1.800 \\
\hline SHG44 & 0.058 & 0.013 & 5.992 & 0.878 & 1.058 \\
\hline
\end{tabular}

Thereafter, membranes were incubated for $1 \mathrm{~h}$ with HRP-labeled secondary antibodies (Amersham Pharmacia Biotech, Uppsala, Sweden), either sheep anti-mouse (diluted 1:2,500) or donkey anti-rabbit $(1: 5,000)$, and the blots were finally developed using an ECL system, according to the manufacturer's instructions (Amersham Bioscience, Buckinghamshire, UK).

\section{Statistical analysis}

Outcome variables are expressed as means \pm standard deviations (SDs). Statistical analysis was performed using SPSS Version 13.0 (SPSS, Chicago, IL). ANOVA was used for data analysis. All statistical tests were twosided, and $P$ values $<0.05$ were considered to be statistically significant.

\section{Results}

\section{Boron uptake}

As expected, $\left[{ }^{10} \mathrm{~B}\right]$ was taken up by U87, U251, and SHG44 cells during incubation for 24 hours in medium containing $50 \mu \mathrm{g}\left[{ }^{10} \mathrm{~B}\right] / \mathrm{ml}$. The boron concentrations in cells eventually reached $2.72 \pm 0.25 \mu \mathrm{g} / 10^{7}$ cells, $9.78 \pm 0.49 \mu \mathrm{g} / 10^{7}$ cells, and $2.48 \pm 0.34 \mu \mathrm{g} / 10^{7}$ cells for the U87, U251, and SHG44 cell lines, respectively, at $24 \mathrm{~h}$ (Figure 1).

\section{Tumor cell numbers fall after BPA-BNCT treatment}

The inhibitory effect of BPA-BNCT on proliferation of U87 cells was much more significant than that afforded by $\gamma$-rays, as confirmed by the MTT assay $(P<0.01$, Figure 2). Any inhibitory effect was marginal in cells

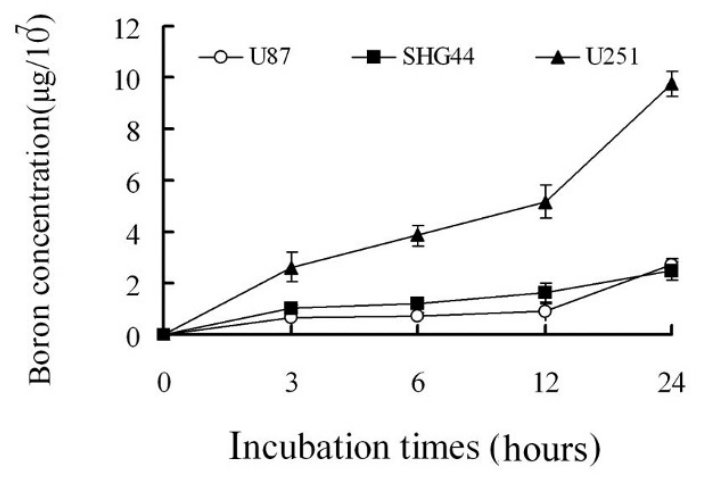

Figure 1 Time course of boron accumulation. Data represent the mean \pm SD of triplicate experiments. receiving 4 Gy or 8 Gy of $\gamma$-rays, whereas significant inhibition was observed in cells treated with 4 Gy or 8 Gy of BPA-BNCT. The number of viable U87 cells decreased in $48 \mathrm{~h}$ after treatment in all of Groups D, E, F, G, H, and I, and the most potent inhibition was observed in the group receiving 8 Gy of BPA-BNCT. Similar effects were observed in SHG44 and U251 cells (data not shown).

\section{BNCT induces apoptosis}

Typical apoptotic morphological changes were found in all of the U87, U251, and SHG44 cell lines $12 \mathrm{~h}$ after treatment with BPA-BNCT; the changes included shrinkage, deformation, and detachment from culture dishes. Nuclear condensation and chromatin margination were evident by Hoechst 33342 staining (Figure 3A, $3 \mathrm{~B}$ ), and chromatin margination, nuclear condensation, and segmentation were noted on transmission electron microscopy (Figure 3C).

The apoptotic frequency of U87 cells treated with 4 Gy or 8 Gy of BPA-BNCT was significantly higher than that of cells treated with equivalent doses of $\gamma$-rays $(P<0.01)$, as shown by annexin V/PI staining (Figure 4, 5). Furthermore, the apoptotic frequency of cells treated with $8 \mathrm{~Gy}$

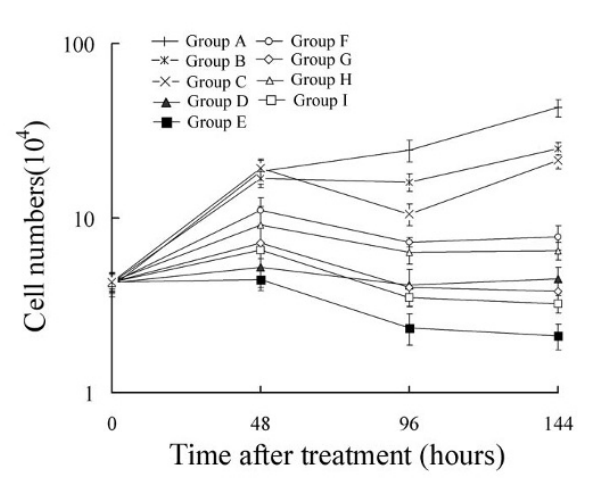

Figure 2 Growth curves of U87 cells in different groups. Group A; control nonirradiated cells; Group B: cells treated with 4 Gy of $\left[{ }^{60} \mathrm{Co}\right] \gamma$-rays; Group C: cells treated with 8 Gy of $\left[{ }^{60} \mathrm{Co}\right] \gamma$-rays; Group D: cells treated with 4 Gy BPA-BNCT; Group E: cells treated with 8 Gy BPA-BNCT; Group F: cells irradiated in the reactor for the same treatment period as used for Group D; Group G: cells irradiated in the reactor for the same treatment period as used for Group E; Group H: cells irradiated with 4 Gy in the reactor; Group I: cells irradiated with 8 Gy in the reactor. Data represent the mean \pm SD of triplicate experiments. 


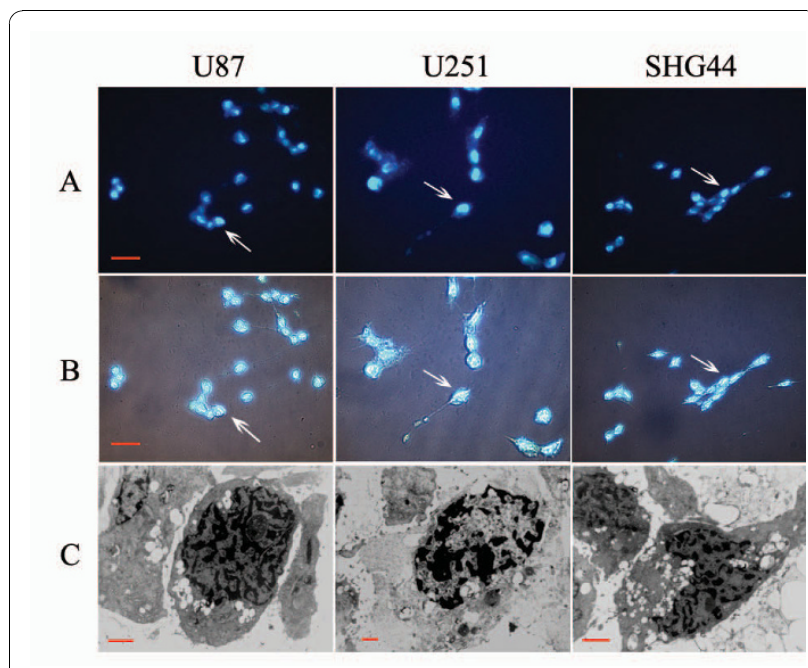

Figure 3 Morphologic changes in glioma cells following BPABNCT treatment. (A) Hoechst staining. White arrows indicate apoptotic cells in U87 cells, U251 cells, and SHG44 cells, respectively. Original magnification $\times 400$; bar: $10 \mu \mathrm{m}$. (B) Phase-contrast microscopy. White arrows indicate apoptotic cells in U87 cells, U251 cells, and SHG44 cells, respectively. Original magnification $\times 400$; bar: $10 \mu \mathrm{m}$. (C) Transmission electron microscopy. Left, U87 cells; original magnification $\times 6,000$; bar: $1 \mu \mathrm{m}$; middle, U251 cells; original magnification $\times 5,000$; bar: $1 \mu \mathrm{m}$; right, SHG44 cells; original magnification $\times 6,000$; bar: $1 \mu \mathrm{m}$.

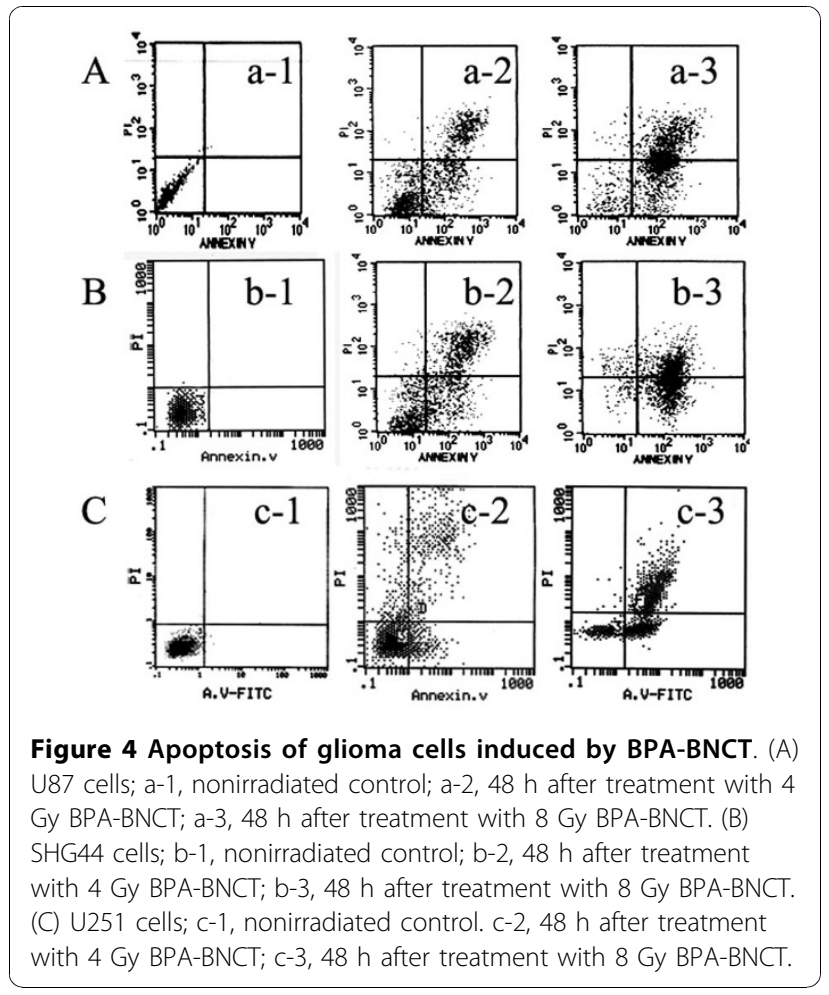

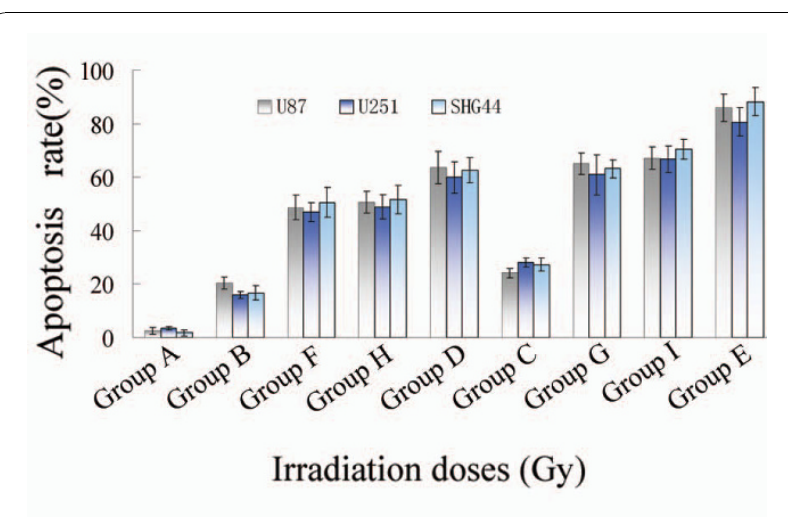

Figure 5 At $48 \mathrm{~h}$ after irradiation the apoptotic frequencies of glioma cells in the nine groups. Group A; control nonirradiated cells; Group B: cells treated with 4 Gy of $\left[{ }^{60} \mathrm{Co}\right] \gamma$-rays; Group C: cells treated with 8 Gy of $\left[{ }^{60} \mathrm{Co}\right] \gamma$-rays; Group D: cells treated with 4 Gy BPA-BNCT; Group E: cells treated with 8 Gy BPA-BNCT; Group F: cells irradiated in the reactor for the same treatment period as used for Group D; Group G: cells irradiated in the reactor for the same treatment period as used for Group E; Group H: cells irradiated with 4 Gy in the reactor; Group I: cells irradiated with 8 Gy in the reactor. Data represent the mean \pm SD of triplicate experiments.

BPA-BNCT was higher than that seen after treatment with 4 Gy BPA-BNCT $(P<0.01)$. Also, the apoptotic frequencies of U87 cells after BPA-BNCT treatment were greater than those noted after delivery of equivalent reactor doses of irradiation $(P<0.05)$. Similar effects were observed in SHG44 and U251 cells (Figure 4, 5).

\section{BNCT inhibits colony formation}

The survival rates of nonirradiated control cells were set at $100 \%$. Cell survival proportions were shown in Table 5. Survival analysis of U87, U251, and SHG44 cells showed that all three cell lines were inhibited more potently by BNCT than by irradiation with $\left[{ }^{60} \mathrm{Co}\right] \gamma$-rays $(P<0.01)$ or by general reactor neutron irradiation $(P<0.01)$.

\section{Altered expression of $\mathrm{BCl}-2$ and Bax after BNCT}

In all of U87, U251, and SHG44 cells, Bcl-2 was initially abundantly expressed, whereas Bax expression was low. After treatment with 4 Gy or 8 Gy of BPA-BNCT, Bcl-2 expression was down-regulated, while Bax expression increased simultaneously. Furthermore, $24 \mathrm{~h}$ after treatment with 4 Gy BPA-BNCT, Bcl-2 expression was lower than that seen $12 \mathrm{~h}$ after treatment with 4 Gy BPA$\mathrm{BNCT}$, and the level of Bax expression was higher. The levels of Bcl-2 and Bax expression were similar $12 \mathrm{~h}$ and $24 \mathrm{~h}$ after treatment with 8 Gy BPA-BNCT (Figure 6).

\section{Discussion}

Two criteria must be fulfilled when BNCT is to be applied: an appropriate source of high-flux thermal neutrons is necessary, along with a boron carrier that is 
Table 5 Survival fractions of glioma cells in different groups

\begin{tabular}{|c|c|c|c|}
\hline \multirow[t]{2}{*}{ Group } & \multicolumn{3}{|c|}{ Survival fraction (\%) } \\
\hline & U87 & U251 & SHG44 \\
\hline Unirradiated control (A) & 100 & 100 & 100 \\
\hline Irradiated in ${ }^{60}$ Co by 4 Gy (B) & 68.1 & 63.7 & 64.5 \\
\hline Irradiated in ${ }^{60} \mathrm{Co}$ by $8 \mathrm{~Gy}(\mathrm{C})$ & 10.9 & 13.6 & 12.4 \\
\hline Irradiated in reactor for the same treatment period as used for Group D (F) & 3.1 & 2.3 & 2.5 \\
\hline Irradiated in reactor for the same treatment period as used for Group E (G) & 1.6 & 1.4 & 1.6 \\
\hline Irradiated in reactor by 4 Gy $(\mathrm{H})$ & 2.9 & 2.2 & 2.6 \\
\hline Irradiated in reactor by 8 Gy $(I)$ & 1.4 & 0.9 & 1.2 \\
\hline Irradiated in reactor with BNCT by 4 Gy (D)* & $<0.01 \%$ & $<0.01 \%$ & $<0.01 \%$ \\
\hline Irradiated in reactor with BNCT by $8 \mathrm{~Gy}(\mathrm{E})^{* *}$ & $<0.01 \%$ & $<0.01 \%$ & $<0.01 \%$ \\
\hline
\end{tabular}

${ }^{*} P<0.01$ vs $A, B, F$ and $H{ }^{* *} P<0.01$ vs $A, C, G, I$ and $D$

able to concentrate in glioma tissues. Therefore, we initially verified uptake of BPA by glioma cells in vitro. We found that the boron concentration in the three glioma cell lines increased constantly over the first 24 hours of incubation. Irradiation was conducted at this time, and the $\left[{ }^{10} \mathrm{~B}\right]$ level attained the theoretical requirement, in that at least $10^{9}\left[{ }^{10} \mathrm{~B}\right]$ atoms accumulated in each glioma cell and the thermal neutron fluence could attain $10^{12}-10^{13} \mathrm{n} \cdot \mathrm{cm}^{-2}$, to produce a lethal discharge of high-LET particles [20].

BNCT can inhibit cell proliferation because the RBE is high, as has been shown in animal models. In the present study, although the three glioma cell lines differed in boron concentration after exposure to BPA, the therapeutic efficiency of BNCT was similar in all three lines because the RBE was high. Proliferation of glioma cells was significantly suppressed by BNCT, and the clonogenicity of glioma cells after BNCT treatment was less than $0.01 \%$ of control values.

Apoptosis, an active process of cellular suicide, is an important means of radiation-induced cell death [21], and may contribute to the therapeutic efficacy of BNCT. Many triggers of apoptosis are known, including cytogenetic alterations such as micronuclei (MN) formation and chromosomal aberrations (CA) within cellular systems [22]. Furthermore, several studies have sought to correlate the extent of apoptosis after irradiation with

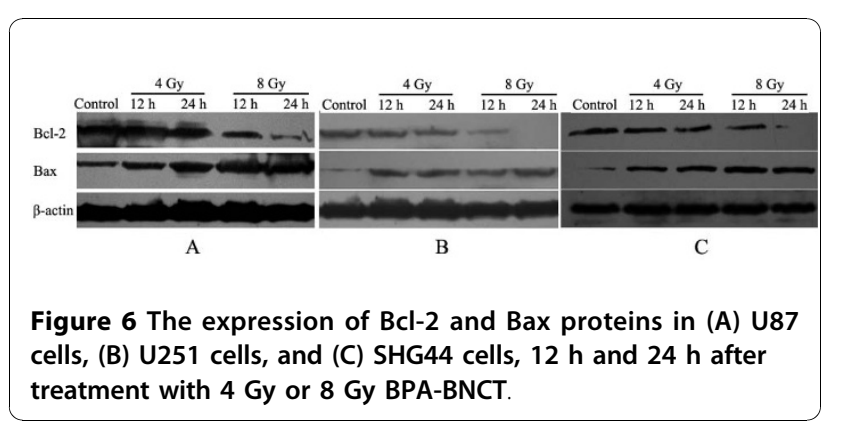

cellular radiosensitivity [23]. Given that BNCT works mainly through the discharge effects of high-LET Li nuclei and $\alpha$ particles, we investigated whether BNCT could induce apoptosis of glioma cells. Typical apoptotic morphological changes were confirmed in U87, U251, and SHG44 cells after BNCT treatment, using transmission electron microscopy and Hoechst 33342 staining. Furthermore, previous studies have shown that BPA has no toxicity effect on cells at a dosage up to $110 \mu \mathrm{g}$ $\left[{ }^{10} \mathrm{~B}\right] / \mathrm{ml}[24]$. Few apoptotic changes were apparent in nonirradiated control cells, showing, for the first time, that the pro-apoptotic effect of BNCT plays an important role in the reduction of cell proliferation. Masunaga et al. described that BNCT induced apoptosis in vivo, the proportion of apoptotic cells increased slightly $6 \mathrm{~h}$ after BNCT, and the apoptotic rate was relatively low $[17,18]$. Fujita et al. stated that apoptosis was a form of cell death induced by BNCT [25]. While Aromando et al. reported that apoptosis did not have a significant role in BNCT-induced hamster cheek pouch tumor control [26], and Kamida et al. described that differences in apoptotic cells pre- and post-BNCT in human oral squamous cell carcinoma xenografts were minimal [27]. Whether BNCT can induce significant apoptosis rate in glioma cells in vivo and whether the pro-apoptotic effect is cell-type-dependant deserved further study.

It is well established in mammalian systems that highLET irradiations have more pronounced effects on biological systems than that of low LET [22], owing to the characteristic mode of energy deposition along a track. Such energy generates complex forms of radiation damage to biological molecules. The transfer of the energy of high-LET radiation to such molecules can break chemical bonds and ionize various cellular components.

In the present study, AnnexinV/PI analysis not only confirmed the pro-apoptotic effect of BNCT, but also showed that apoptosis frequencies were higher in groups treated with BNCT compared with $\gamma$-rays. Moreover, the 
apoptotic frequencies in BPA-BNCT groups were higher than those of the irradiated controls. Additionally, when the absorbed doses were identical, both the proliferation and the clonogenicity of glioma cells were suppressed by BNCT to an extent significantly greater than seen after exposure to a neutron beam. Thus, the RBE of BNCT is higher than that of either a neutron beam or $\gamma$-rays. In the present study, the contribution of a borondependent dose to the total BNCT dose was low. Thus, with optimization of the reactor and improvement in the boron-dependent dose, the RBE of BNCT can be further increased.

Previous studies have shown that the intrinsic apoptotic pathway (involving the mitochondria) plays a key role in the regulation of apoptosis in response to irradiation [28]. Bcl-2 family proteins interact to permeabilize the mitochondrial membrane, thus playing an important role in irradiation-induced apoptosis [29-31]. Bcl-2 and Bax, the two main members of the Bcl-2 protein family, function as tumor anti-apoptotic and pro-apoptotic factors, respectively [32-34]. Bax can cause release of cytochrome c after formation of the hetero-oligomer Bax/ Bak, whereas Bcl-2 can engage with activator proteins or Bax/Bak, thereby sequestering these proteins [28]. We detected expression of Bcl-2 and Bax in all of U87, U251, and SHG44 cells after BNCT treatment in efforts to understand the impact of BNCT on the mitochondrial pathway of apoptosis. Down-regulation of Bcl-2 and up-regulation of Bax synthesis after BNCT showed that apoptosis induced by BNCT may be mediated through the mitochondrial pathway.

A Bcl-2 antisense has been developed as a gene therapeutic agent to treat cancer, such as: melanoma carcinoma, multiple myeloma, and small cell lung cancer [28]. Elimination of Bcl-2 induced by BNCT indicates that a directed Bcl-2-targeting strategy may be combined with BNCT, thus possibly leading to synergistic reduction of $\mathrm{Bcl}-2$; this possibility deserves further investigation.

Our investigation of BPA-BNCT therapy was conducted in vitro, and many constraints are involved in attempts to extrapolate in vitro data to the in vivo context. During BNCT, the normal brain tissue and tumors are non-specifically irradiated by reactor-generated mixed irradiation beam components, and the patient tolerance to BNCT could be impaired. When it is considered that the RBE of BNCT is higher than that of $\gamma$ rays, neutron beam, and X-rays, all of which are widely used as treatment options for patients with brain tumors, the absorbed dose from BNCT can be much lower than those strategies. This will limit irradiation damage to normal tissue. The boron level in blood and brain parenchyma also contributes to the irradiation dose to normal tissue. With the development of boron containing agents and the optimization of strategies of delivery, $\left[{ }^{10} \mathrm{~B}\right]$ can be highly accumulated in tumor cells and the level in normal cells becomes relatively lower $[2,13,35,36]$. Moreover, BNCT relies mainly on the use of boron compounds, and not on a neutron beam per $s e$, to selectively irradiate a tumor [37]. Thus, the optimization of selective boron delivery to tumor cells is an important area of BNCT research. As known the BBB can impede the uptake of boron-containing compounds by tumor cells, with the invasive properties of glioma tumors, the BBB can be destroyed and the boron uptake by tumor cells could be increased. Drugs such as mannitol that transiently compromise BBB integrity have been used to improve boron absorbance by tumor cells. Overall, the use of BNCT in vivo will likely become effective, with a reduction in side effects and improvements in tumor-targeting boron compounds, following further development.

\section{Conclusions}

Altogether, induction of apoptosis contributes to the main therapeutic efficacy of BNCT to glioma cells in vitro. Activation of Bax and downregulation of Bcl-2 are involvement in the apoptosis triggered by BNCT. Moreover, the RBE of BPA-BNCT is higher than that of $\gamma$-ray and reactor neutron irradiation. Understanding the mechanisms involved in BNCT will ultimately contribute to the enhancement of the therapeutic effectiveness of this therapeutic modality.

\section{Acknowledgements}

This research was supported by the National Natural Science Foundation (No: 10375047), Beijing, P.R. China.

\section{Author details}

'Department of Neurosurgery of Xijing Hospital, Fourth Military Medical University, Xi'an, Shaanxi 710032, P.R.China. ${ }^{2}$ Northwest Institute of Nuclear Technology, Xi'an, Shaanxi 710024, PR China. ${ }^{3}$ Department of Biochemistry and Molecular Biology, Fourth Military Medical University, Xi'an, Shaanxi 710032, PR China.

\section{Authors' contributions}

Peng Wang, Haining Zhen, and Xinbiao Jiang carried out the cell culture and experiment of irradiation. Peng Wang and Xin Cheng carried out Proliferation assays, Hoechst staining, Electron microscopy assay, AnnexinV/PI analysis, Colony formation assay, and drafted the manuscript. Wei Zhang, Geng Guo, and Xinggang Mao participated in the design of the study and performed the statistical analysis. Xiang Zhang conceived of the study, and participated in its design and coordination. All authors read and approved the final manuscript.

\section{Competing interests}

The authors declare that they have no competing interests.

Received: 8 February 2010 Accepted: 2 December 2010 Published: 2 December 2010

\section{References}

1. Barth RF, Joensuu $\mathrm{H}$ : Boron neutron capture therapy for the treatment of glioblastomas and extracranial tumours: as effective, more effective or less effective than photon irradiation? Radiother Oncol 2007, 82:119-122. 
2. Yang W, Barth RF, Wu G, Huo T, Tjarks W, Ciesielski M, Fenstermaker RA, Ross BD, Wikstrand CJ, Riley KJ, Binns PJ: Convection enhanced delivery of boronated EGF as a molecular targeting agent for neutron capture therapy of brain tumors. J Neurooncol 2009, 95:355-365.

3. Barth RF, Coderre JA, Vicente MG, Blue TE: Boron neutron capture therapy of cancer: current status and future prospects. Clin Cancer Res 2005, 11:3987-4002.

4. Yang W, Barth RF, Wu G, Bandyopadhyaya AK, Thirumamagal BT, Tjarks W, Binns PJ, Riley K, Patel H, Coderre JA, Ciesielski MJ, Fenstermaker RA: Boronated epidermal growth factor as a delivery agent for neutron capture therapy of EGF receptor positive gliomas. Appl Radiat Isot 2004, 61:981-985.

5. Barth RF, Yang W, Coderre JA: Rat brain tumor models to assess the efficacy of boron neutron capture therapy: a critical evaluation. $J$ Neurooncol 2003, 62:61-74.

6. Barth RF: Boron neutron capture therapy at the crossroads: challenges and opportunities. Appl Radiat Isot 2009, 67:S3-S6.

7. Yang W, Barth RF, Carpenter DE, Moeschberger ML, Goodman JH: Enhanced delivery of boronophenylalanine for neutron capture therapy by means of intracarotid injection and blood-brain barrier disruption. Neurosurgery 1996, 38:985-992.

8. Barth RF, Yang W, Rotaru JH, Moeschberger ML, Boesel CP, Soloway $A H$, Joel DD, Nawrocky MM, Ono K, Goodman JH: Boron neutron capture therapy of brain tumors: enhanced survival and cure following bloodbrain barrier disruption and intracarotid injection of sodium borocaptate and boronophenylalanine. Int J Radiat Oncol Biol Phys 2000 47:209-218.

9. Barth RF, Yang W, Rotaru JH, Moeschberger ML, Joel DD, Nawrocky MM, Goodman JH, Soloway AH: Boron neutron capture therapy of brain tumors: enhanced survival following intracarotid injection of either sodium borocaptate or boronophenylalanine with or without bloodbrain barrier disruption. Cancer Res 1997, 57:1129-1136.

10. Yang W, Barth RF, Adams DM, Ciesielski MJ, Fenstermaker RA, Shukla S, Tjarks W, Caligiuri MA: Convection-enhanced delivery of boronated epidermal growth factor for molecular targeting of EGF receptorpositive gliomas. Cancer Res 2002, 62:6552-6558.

11. Kato I, Fujita Y, Maruhashi A, Kumada H, Ohmae M, Kirihata M, Imahori Y, Suzuki M, Sakrai Y, Sumi T, Iwai S, Nakazawa M, Murata I, Miyamaru H, Ono K: Effectiveness of boron neutron capture therapy for recurrent head and neck malignancies. Appl Radiat Isot 2009, 67:S37-S42.

12. Barth RF, Kaur B: Rat brain tumor models in experimental neurooncology: the C6, 9L, T9, RG2, F98, BT4C, RT-2 and CNS-1 gliomas. J Neurooncol 2009, 94:299-312.

13. Kawabata S, Miyatake S, Nonoguchi N, Hiramatsu R, lida K, Miyata S, Yokoyama K, Doi A, Kuroda Y, Kuroiwa T, Michiue H, Kumada H, Kirihata M Imahori Y, Maruhashi A, Sakurai Y, Suzuki M, Masunaga S, Ono K: Survival benefit from boron neutron capture therapy for the newly diagnosed glioblastoma patients. Appl Radiat Isot 2009, 67:S15-S18.

14. Miyatake S, Kawabata S, Yokoyama K, Kuroiwa T, Michiue H, Sakurai Y, Kumada H, Suzuki M, Maruhashi A, Kirihata M, Ono K: Survival benefit of Boron neutron capture therapy for recurrent malignant gliomas. J Neurooncol 2009, 91:199-206.

15. Gonzalez SJ, Bonomi MR, Santa CG, Blaumann HR, Calzetta LO, Menendez P, Jimenez RR, Longhino J, Feld DB, Dagrosa MA, Argerich C, Castiglia SG, Batistoni DA, Liberman SJ, Roth BM: First BNCT treatment of a skin melanoma in Argentina: dosimetric analysis and clinical outcome. Appl Radiat Isot 2004, 61:1101-1105.

16. Yoshida F, Matsumura A, Shibata Y, Yamamoto T, Nakauchi H, Okumura M, Nose T: Cell cycle dependence of boron uptake from two boron compounds used for clinical neutron capture therapy. Cancer Lett 2002, 187:135-141.

17. Masunaga S, Ono K, Takahashi A, Sakurai Y, Ohnishi K, Kobayashi T, Kinashi Y, Takagaki M, Ohnishi T: Impact of the p53 status of the tumor cells on the effect of reactor neutron beam irradiation, with emphasis on the response of intratumor quiescent cells. Jpn J Cancer Res 2002, 93:1366-1377.
18. Masunaga S, Ono K, Sakurai Y, Takagaki M, Kobayashi T, Kinashi Y, Suzuki M: Evaluation of apoptosis and micronucleation induced by reactor neutron beams with two different cadmium ratios in total and quiescent cell populations within solid tumors. Int J Radiat Oncol Biol Phys 2001, 51:828-839.

19. Busse D, Doughty RS, Ramsey $\Pi$, Russell WE, Price JO, Flanagan WM, Shawver LK, Arteaga CL: Reversible G(1) arrest induced by inhibition of the epidermal growth factor receptor tyrosine kinase requires upregulation of p27(KIP1) independent of MAPK activity. J Biol Chem 2000, 275:6987-6995.

20. Barth RF, Soloway AH, Goodman JH, Gahbauer RA, Gupta N, Blue TE, Yang W, Tjarks W: Boron neutron capture therapy of brain tumors: an emerging therapeutic modality. Neurosurgery 1999, 44:433-450, 450-451.

21. Verheij M, Bartelink H: Radiation-induced apoptosis. Cell Tissue Res 2000 301:133-142

22. Pathak R, Dey SK, Sarma A, Khuda-Bukhsh AR: Genotoxic effects in M5 cells and Chinese hamster V79 cells after exposure to 7Li-beam (LET = $60 \mathrm{keV} / \mathrm{microm}$ ) and correlation of their survival dynamics to nuclear damages and cell death. Mutat Res 2007, 628:56-66.

23. Lee HJ, Kim JS, Moon C, Kim JC, Jo SK, Kim SH: Relative biological effectiveness of fast neutrons in a multiorgan assay for apoptosis in mouse. Environ Toxicol 2008, 23:233-239.

24. Dahlstrom M, Capala J, Lindstrom P, Wasteson A, Lindstrom A: Accumulation of boron in human malignant glioma cells in vitro is cell type dependent. J Neurooncol 2004, 68:199-205.

25. Fujita Y, Kato I, Iwai S, Ono K, Suzuki M, Sakurai Y, Ohnishi K, Ohnishi T, Yura Y: Role of p53 mutation in the effect of boron neutron capture therapy on oral squamous cell carcinoma. Radiat Oncol 2009, 4:63.

26. Aromando RF, Heber EM, Trivillin VA, Nigg DW, Schwint AE, Itoiz ME: Insight into the mechanisms underlying tumor response to boron neutron capture therapy in the hamster cheek pouch oral cancer model. J Oral Pathol Med 2009, 38:448-454.

27. Kamida A, Obayashi S, Kato I, Ono K, Suzuki M, Nagata K, Sakurai Y, Yura Y: Effects of boron neutron capture therapy on human oral squamous cell carcinoma in a nude mouse model. Int J Radiat Biol 2006, 82:21-29.

28. Kang $\mathrm{MH}$, Reynolds $\mathrm{CP}$ : Bcl-2 inhibitors: targeting mitochondrial apoptotic pathways in cancer therapy. Clin Cancer Res 2009, 15:1126-1132.

29. Oltersdorf T, Elmore SW, Shoemaker AR, Armstrong RC, Augeri DJ, Belli BA, Bruncko M, Deckwerth TL, Dinges J, Hajduk PJ, Joseph MK, Kitada S, Korsmeyer SJ, Kunzer AR, Letai A, Li C, Mitten MJ, Nettesheim DG, Ng S, Nimmer PM, O'Connor JM, Oleksijew A, Petros AM, Reed JC, Shen W, Tahir SK, Thompson CB, Tomaselli KJ, Wang B, Wendt MD, Zhang H, Fesik SW, Rosenberg SH: An inhibitor of Bcl-2 family proteins induces regression of solid tumours. Nature 2005, 435:677-681.

30. Hotchkiss RS, Strasser A, McDunn JE, Swanson PE: Cell death. N Engl J Med 2009, 361:1570-1583.

31. Zerp SF, Stoter R, Kuipers G, Yang D, Lippman ME, van Blitterswijk WJ, Bartelink H, Rooswinkel R, Lafleur V, Verheij M: AT-101, a small molecule inhibitor of anti-apoptotic Bcl-2 family members, activates the SAPK/JNK pathway and enhances radiation-induced apoptosis. Radiat Oncol 2009, 4:47.

32. Ciardiello F, Tortora G: Inhibition of bcl-2 as cancer therapy. Ann Oncol 2002, 13:501-502.

33. Kim KW, Moretti L, Mitchell LR, Jung DK, Lu B: Combined Bcl-2/mammalian target of rapamycin inhibition leads to enhanced radiosensitization via induction of apoptosis and autophagy in non-small cell lung tumor xenograft model. Clin Cancer Res 2009, 15:6096-6105.

34. Snyder CM, Shroff EH, Liu J, Chandel NS: Nitric oxide induces cell death by regulating anti-apoptotic BCL-2 family members. PLoS One 2009, 4 e7059.

35. Capuani S, Gili T, Bozzali M, Russo S, Porcari P, Cametti C, Muolo M D'Amore E, Maraviglia B, Lazzarino G, Pastore FS: Boronophenylalanine uptake in C6 glioma model is dramatically increased by L-DOPA preloading. Appl Radiat Isot 2009, 67:S34-S36.

36. Barth RF, Yang W, Wu G, Swindall M, Byun Y, Narayanasamy S, Tjarks W Tordoff K, Moeschberger ML, Eriksson S, Binns PJ, Riley KJ: Thymidine 
kinase 1 as a molecular target for boron neutron capture therapy of brain tumors. Proc Natl Acad Sci USA 2008, 105:17493-17497.

37. Coderre JA, Gavin PR, Capala J, Ma R, Morris GM, Button TM, Aziz T,

Peress NS: Tolerance of the normal canine brain to epithermal neutron irradiation in the presence of p-boronophenylalanine. J Neurooncol 2000, 48:27-40.

\section{Pre-publication history}

The pre-publication history for this paper can be accessed here: http://www.biomedcentral.com/1471-2407/10/661/prepub

doi:10.1186/1471-2407-10-661

Cite this article as: Wang et al:: Boron neutron capture therapy induces apoptosis of glioma cells through Bcl-2/Bax. BMC Cancer 2010 10:661.

Submit your next manuscript to BioMed Central and take full advantage of:

- Convenient online submission

- Thorough peer review

- No space constraints or color figure charges

- Immediate publication on acceptance

- Inclusion in PubMed, CAS, Scopus and Google Scholar

- Research which is freely available for redistribution

Submit your manuscript at www.biomedcentral.com/submit
C Biomed Central 